\title{
弾性シート間の粘性流体のメニスカス不安定性に対する線形安定性解析
}

\author{
宗高大和 $* 1$, 古口 日出男 $* 2$
}

\section{Linear stability analysis for the meniscus instability of a viscous fluid between elastic sheets}

\author{
Yamato MUNETAKA*1 and Hideo KOGUCHI ${ }^{* 2}$ \\ ${ }^{* 1}$ Graduate School of Nagaoka University of Technology, Dept. of Mechanical Engineering \\ 1603-1 Kamitomioka-machi, Nagaoka-shi, Niigata 940-2188, Japan \\ *2 Nagaoka University of Technology, Dept. of Mechanical Engineering \\ 1603-1 Kamitomioka-machi, Nagaoka-shi, Niigata 940-2188, Japan
}

\section{Received 19 December 2014}

\begin{abstract}
When two parallel plates confining a viscous fluid in a narrow gap between their plates separate from each other at a constant velocity, the free surface of the fluid disturbs like a dendrite or fingers. This phenomenon is referred to as meniscus instability. In the present study, the meniscus instability of a viscous fluid between two elastic sheets bonded to rigid substrates was examined theoretically and experimentally. Linear stability analysis was performed to obtain the wavelength of disturbances on free surface of the fluid. The elastic sheet was modeled by a linear spring in order to take into account of the deformation of elastic sheets. The wavelength was measured by using a video camera in experiment. These results were well agreed with each other by considering a normal viscous stress at the interface and the effect of the thickness of fluid film remaining on the plates. The minimum wavelength predicting from the theory was about 3.2 times larger as the initial film thickness of the fluid, and the experimental ones were about 3.0 to 5.0 times. The experimental wavelength in the elastic sheets was smaller than that in the parallel plates like as theoretical ones. This result suggests that deformation of the elastic sheets destabilizes the free surface of the fluid.
\end{abstract}

Key words : Meniscus instability, Elastic sheet, Capillary number, Hele-Shaw flow

\section{1. 緒言}

平行な 2 枚の板の狭いすき間に粘性流体を満たすと，空気と流体との気液界面（自由表面）は毛細管現象によつ て湾曲し，メニスカスが形成される。その後，流体を挟んだ板を一定速度で引き離すと，流体には絞り膜効果によつ て負圧が生じ，メニスカスの先端が板の内部に移動しながら流体膜が分離していく．このとき，流体の粘度や板を 引き離す速度が大きな場合，自由表面が複雑な樹枝状パターンを形成する。このように自由表面が乱れる現象はメ ニスカス不安定現象と呼ばれ，ロールコーティングの塗膜 (山村，2009，佐々木，2014)，粘着性フィルムの剥離面 (Ghatak, et al., 2000, Ghatak, et al., 2005, Chung, et al., 2006)，すべり軸受内の油膜破断 (Grillet and Shaqfeh, 1999), 結晶成長 (Glicksman and Lupulescu, 2004, Bales, et al., 1989), 非晶質材料の引張破断面 (Qu and Zhang, 2013) など 広範な領域で観察されており，物体の分離・破断に伴う基礎的な現象であると考えられる.

メニスカス不安定性の研究として, Saffman と Taylor に始まる Hele-Shaw セル内の流れの研究が有名である (Saffman and Taylor, 1958, Saffman, 1986). Hele-Shaw セルとは平行平板間の狭いすき間に粘度の高い流体を満た

No.14-00686 [DOI:10.1299/transjsme.14-00686], J-STAGE Advance Publication date : 27 February, 2015]

*1 正員, 長岡技術科学大学大学院 工学研究科 (T 940-2188 新潟県長岡市上富岡町 1603-1)

*2 正員, フェロー, 長岡技術科学大学工学部

E-mail of corresponding author: s103097@ stn.nagaokaut.ac.jp 


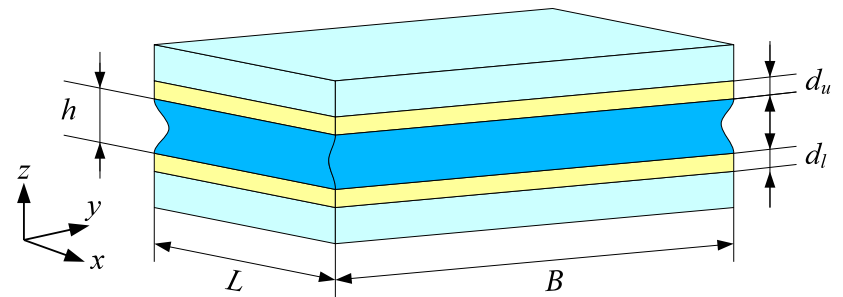

(a) Overall view

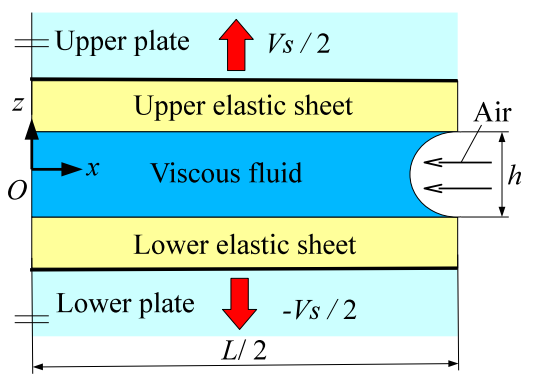

(b) Cross sectional view

Fig. 1 Schematic view of analysis model. Incompressible viscous fluid is confined between two elastic sheets bonded to rigid substrates. In the above figures, the Young 's modulus of the upper and lower elastic sheets are $E_{u}$ and $E_{l}$, respectively. The thickness of the upper and lower sheets are $d_{u}$ and $d_{l}$, respectively. The length and width of the elastic sheets are $L$ and $B$, respectively. $\mu$ is the viscosity of the fluid and $V_{s}$ is the separation rate.

したもので，その中に別の低粘度の流体を注入すると，流体界面が一様には入り込まず，Viscous Fingering と呼ば れるパターンが形成される。この現象は水や空気の圧入によって地盤内の油層の石油を押し出して採収する石油 掘削の問題に端を発し, 現在でも二酸化炭素貯留に関連して石油増進回収法 (Enhanced Oil Recovery) の分野など で研究が行われている (Hidalgo and Carrera, 2009).

Saffman と Taylor は Hele-Shaw セル内の粘度の異なる 2 つの流体の界面に対して線形安定性解析を行い, 界面 の安定性がキャピラリ数で整理できることを示した (Saffman and Taylor, 1958)。 キャピラリ数とは流体の表面張 力と粘性力の比によって定義される無次元数で, キャピラリ数が大きくなると界面が不安定になり, 乱れの波長 も小さくなる. McLean と Saffman は同様の系に対して表面張力の影響を考慮した解析を行い, 油で満たされた Hele-Shaw セル内に空気を注入したときの自由表面の形状を調べた Pittsの実験と, 形状のプロファイルが定量的 に一致することを示した (McLean and Saffman, 1981, Pitts, 1980). Park と Homsy はメニスカス界面上の圧力の境 界条件をキャピラリ数の関数として導き, キャピラリ数が微小な範囲において理論解析と実験結果が一致するこ とを示した (Park and Homsy, 1984, Park, et al., 1984). Reinelt はさらに板面上の残留液膜を考慮した境界条件を導 いた (Reinelt, 1987)。板のすき間に満たした粘性流体を引き離す場合の自由表面の乱叔についても理論的および実 験的な研究が多く行われている (古口他, 1987, 古口他, 1988, Shelley, et al., 1997, Lindner, et al., 2005, Nase, et al., 2011)。 また, 古口らは境界要素法による自由表面の乱れのシミュレーションを行い, 残留液膜を考慮することに よって実験結果とよく一致する自由表面のパターンを再現している (古口他, 1994, 古口他, 1995).

ところで, 近年, 自由表面の乱叔のパターンの制御などを目的として, Hele-Shaw セルの片側の板をゲルなぞの 柔軟な弾性膜に置き換えた場合に関する研究が行われている。それらの報告によれば，弾性膜の変形によって乱 れが抑制され，形成されるパターンも平行平板間のそれとは異なるものが観察される (Pihler-Puzović, et al., 2012, Pihler-Puzović, et al., 2013, Pihler-Puzović, et al., 2014, Pihler-Puzović, et al., 2014, Al-Housseiny, et al., 2013). また, 平行平板間の狭いすき間内に設けたキャビティの周囲を柔軟なゲルシートで囲い，キャビティに流体を注入する と, 流体とゲルシートの界面が特徵的なパターンを形成する (Saintyves, et al., 2013, Biggins, et al., 2013).このよ うな系の安定性はキャピラリ数だけでは判断できず, 柔軟な物体と流体が接触している接触面の弾性変形の影響 を考慮しなければならない。

そこで, 本研究では, 粘性流体を挟む板面の弾性変形がメニスカス不安定現象に与える影響について調べるこ とを目的とする。ここでは, 剛体基板に接着された弾性シートの間に粘性流体を挟んだ系を考える. 剛体基板が 互いに一定速度で離れる際の自由表面について, 線形安定性理論によって自由表面上の乱秃成長する条件を乱 れの波長とキャピラリ数の関係式として求め, 実験で観察される波長と比較検討する. 


\section{2. 理 論 解 析}

\section{$2 \cdot 1$ 基礎式の導出}

図 1 に解析モデルの概略図を示す。粘度 $\mu$ の粘性流体が長さ $L$, 幅 $B(>L)$ の矩形弾性シートの間に挟まれて おり，その液膜厚さを $h$ とする。弾性シートの片側は同寸法の剛体基板に接着されており，上下の弾性シートの弾 性定数をそれぞれ $E_{u}, E_{l}$, 厚さを $d_{u}, d_{l}$ とする. また, 静止状態における初期すき間を $h_{0}$, 板を引き離す速度を $V_{s}$ とする.

原点を板の中心かつ液膜の中央に持つ直交座標系を導入し，板の長さ方向を $x$ 軸，幅方向を $y$ 軸，厚さ方向を $z$ 軸とする．まず，解析のための基礎式を導出する，本研究では，粘度の高い流体の遅い流机を対象とするため，流 体は非圧縮であり, 慣性力や重力は粘性力に対して無視できると仮定する。このときの系の支配方程式は Stokes 方程式と連続の式である。

$$
\begin{aligned}
& \frac{\partial p}{\partial x}=\mu\left(\frac{\partial^{2} u}{\partial x^{2}}+\frac{\partial^{2} u}{\partial y^{2}}+\frac{\partial^{2} u}{\partial z^{2}}\right) \\
& \frac{\partial p}{\partial y}=\mu\left(\frac{\partial^{2} v}{\partial x^{2}}+\frac{\partial^{2} v}{\partial y^{2}}+\frac{\partial^{2} v}{\partial z^{2}}\right) \\
& \frac{\partial p}{\partial z}=\mu\left(\frac{\partial^{2} w}{\partial x^{2}}+\frac{\partial^{2} w}{\partial y^{2}}+\frac{\partial^{2} w}{\partial z^{2}}\right) \\
& \frac{\partial u}{\partial x}+\frac{\partial v}{\partial y}+\frac{\partial w}{\partial z}=0
\end{aligned}
$$

ここで， $u, v, w$ はそれぞれ $x, y, z$ 方向の流速， $p$ は圧力である.いま，板のすき間が板の寸法に対して十分小さく $(h \ll L, B)$, 圧力が $z$ 方向に変化しないものとする. また, 速度分布の $x$ および $y$ 方向の変化は $z$ 方向の変化に 比べて無視できるとすると，式(1)から式 (3) は次のようになる.

$$
\begin{aligned}
& \frac{\partial p}{\partial x}=\mu \frac{\partial^{2} u}{\partial z^{2}} \\
& \frac{\partial p}{\partial y}=\mu \frac{\partial^{2} v}{\partial z^{2}} \\
& \frac{\partial p}{\partial z}=0
\end{aligned}
$$

式 (5) と式 (6) から速度 $(u, v)$ を求めるため, 境界条件 $z= \pm h / 2$ で $u=v=0$ の下で $z$ について積分すると, 水平 方向の速度分布を得る。

$$
\begin{aligned}
& u=\frac{1}{2 \mu} \frac{\partial p}{\partial x}\left(z^{2}-\frac{h^{2}}{4}\right) \\
& v=\frac{1}{2 \mu} \frac{\partial p}{\partial y}\left(z^{2}-\frac{h^{2}}{4}\right)
\end{aligned}
$$

すなわち，水平方向の流速は液膜中央 $(z=0)$ で最大值を取る Hagen-Poiseuille 分布となる.

式(8)および式 (9) を連続の式 (4) に代入して境界条件 $z= \pm h / 2 て ゙ ~ w= \pm \dot{h} / 2$ の下で $z$ について積分すると,

$$
\frac{\partial}{\partial x}\left(h^{3} \frac{\partial p}{\partial x}\right)+\frac{\partial}{\partial y}\left(h^{3} \frac{\partial p}{\partial y}\right)=12 \mu \dot{h}
$$

ここで, 右辺の $\dot{h}$ はすき間の相対速度であり, は時間微分を表す。式 (10) は流体潤滑における 2 面がスクイーズ 運動のみを行う場合の Reynolds 方程式に等しい.この式を適当な境界条件の下で解いて圧力分布を求め, 式 (8) と式(9)に代入することで速度分布が得られる。

解析を進める前に式 (10) を無次元化しておく. 次元のある量を改めて $x^{*}$ などと書き，各無次元変数を次のよう に扮く。

$$
x=\frac{x^{*}}{L}, y=\frac{y^{*}}{L}, t=\frac{t^{*}}{h_{0} / V_{s}}, h=\frac{h^{*}}{h_{0}}, p=\frac{p^{*}}{\sigma / L}
$$


ここで， $\sigma$ は流体の表面張力係数である. 本研究のような表面張力の影響が大きな流れでは, 圧力のスケールと して表面張力を用いることが適当であると考えられる，その結果，次の無次元の Reynolds 方程式を得る.

$$
\begin{aligned}
& \frac{\partial}{\partial x}\left(h^{3} \frac{\partial p}{\partial x}\right)+\frac{\partial}{\partial y}\left(h^{3} \frac{\partial p}{\partial y}\right)=12 C a^{\circ} \dot{h} \\
& C a^{\circ}=\frac{\mu V_{s}}{\sigma}\left(\frac{L}{h_{0}}\right)^{3}
\end{aligned}
$$

ここで, $C a^{\circ}$ は修正キャピラリ数と呼ばれる無次元数である.

\section{$2 \cdot 2$ 圧力の基本解}

まず, 自由表面に摂動がない場合の圧力の基本解を求める.いま, 板の幅が板の長さに対して十分大きく $(B \gg L)$, 圧力が $y$ 方向に変化しないとして，そのときの圧力を $p_{0}$ とすると, 次の一次元の Reynolds 方程式を得る.

$$
\frac{d}{d x}\left(h^{3} \frac{d p_{0}}{d x}\right)=12 C a^{\circ} \dot{h}
$$

ところで, 本研究では弾性シートが流体圧力によって変形するため, すき間は圧力の関数である.ここでは, 最 も単純なモデルとして，弾性シートを $z$ 方向のみに変位する線形ばねとして考え，すき間を次のように表す。

$$
\begin{aligned}
& h(x, t)=H(t)+\delta(x, t)=1+t+\alpha p(x, t) \\
& \alpha=\frac{\sigma}{h_{0} L}\left(\frac{d_{u}}{E_{u}}+\frac{d_{l}}{E_{l}}\right)
\end{aligned}
$$

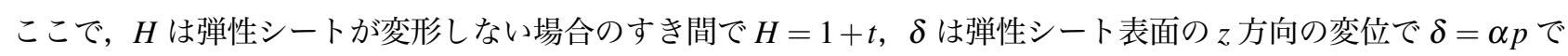
ある． $\alpha$ は弾性パラメータであり, シートの変形しやすさを表す無次元量である. 板を引き離すことによって生じ る圧力は負圧 $p<0$ なので，弾性変形によってすき間は小さくなる.

圧力の境界条件は, 系が板の中心 $x=0$ において $z$ 軸について対称であること, および自由表面上における Young-Laplaceの式から, 次式で与えられる.

$$
\begin{aligned}
& \left.\frac{d p_{0}}{d x}\right|_{x=0}=0 \\
& p_{0}\left(x_{s}\right)=-\frac{2 \beta}{h\left(x_{s}\right)}
\end{aligned}
$$

ここで, $x_{s}$ は $x$ 方向の自由表面の平均位置であり, 式中の $\beta$ は $\beta=L / h_{0}$ である. ここで, $h_{0} \ll 1$ より, メニスカ スの曲率半径が $h / 2$ で与えられるとしている. また, 本研究では弾性シート上の流体は完全濡れの状態（接触角 $\left.=0^{\circ}\right)$ にあると想定する.

式(13) は非線形の偏微分方程式であるため, 厳密解を求めることはできない.ここでは, 板が動き始める極初期 の時点を考えているため, 弾性シートの表面は基板とほぼ同時に動くと仮定し, 式(13)の右辺の $\dot{h} を \dot{h} \approx 1+\dot{\delta}(t)$ とする. その結果, 式 (13) は変数分離して積分することができ, 境界条件 (16) および (17)の下で圧力の基本解が 次式のように求められる.

$$
\begin{aligned}
& p_{0}(x, t)=\frac{1}{\alpha}\left(\sqrt[4]{24 C a^{\circ} \alpha(1+\dot{\delta})\left(x^{2}-x_{s}^{2}\right)+h_{B}^{4}}-H\right) \\
& h_{B}=\frac{1}{2}\left(H+\sqrt{H^{2}-8 \alpha \beta}\right)
\end{aligned}
$$

ここで, $h_{B}$ は自由表面位置におけるすき間であり, $h_{B}=h\left(x_{s}\right)$ である. 上式に含まれる平均変形速度 $\dot{\delta}$ は厳密に は未知であるため, 平行平板間における圧力分布 $p_{r}$ を用いて次のように近似する。すす間の変形が無視できる場 合, $h=H(t), \dot{h}=1$ となるので, 式(13) は次式のように表される.

$$
\frac{d^{2} p_{r}}{d x^{2}}=\frac{12 C a^{\circ}}{H^{3}}
$$




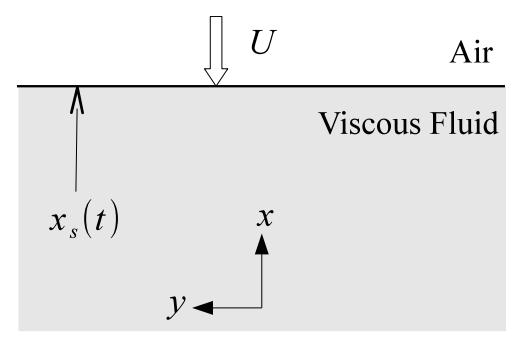

(a) Rectilinear free surface

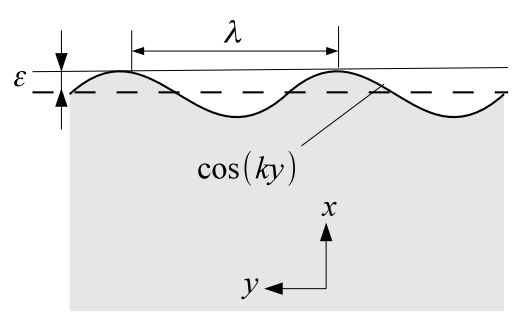

(b) Perturbed free surface

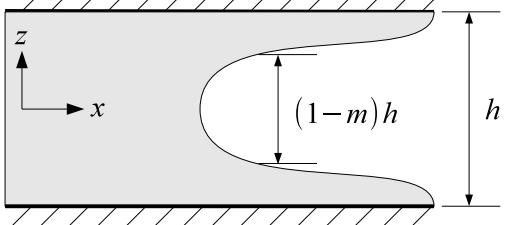

(c) Thin fluid film adhering to the plates

Fig. 2 The illustrations of a perturbation on a rectilinear free surface. (a) The free surface advances in the negative direction of $x$ at a velocity $U . x_{s}$ is the position of the free surface in the $x$-direction. A small amplitude perturbation occurring on the free surface is shown in (b). $\varepsilon, \lambda$ and $k$ are the amplitude of the perturbation, the wavelength and the wave number, respectively. (c) The lateral view at the vicinity of the meniscus surface. After the viscous fluid is displaced by air, a thin fluid film remains on the plate. $m$ is the ratio of the thickness of total fluid film and the remaining film.

式 (20)を式 (16) および (17) と同様の境界条件の下で $x$ について積分すれば，次式が求まる.

$$
p_{r}(x, t)=\frac{6 C a^{\circ}}{H^{3}}\left(x^{2}-x_{s}^{2}\right)-\frac{2 \beta}{H}
$$

これより，平均変形速度 $\dot{\delta}$ を次式のように計算して求める。

$$
\dot{\delta}(t) \approx \alpha \frac{d}{d t} \frac{1}{x_{s}} \int_{0}^{x_{s}} p_{r}(x, t) d x=\frac{\alpha}{H^{6}}\left(5 C a^{\circ}+2 \beta H^{4}\right)
$$

\section{$2 \cdot 3$ 線形安定性解析}

次に，自由表面上に微小な振幅の摂動が生じた場合の線形安定性解析を行う。図 2(a)のように $x$ 軸の負の方向 に速度 $U$ で移動する直線状の自由表面が拱動を受け，図 2(b) のようになったとする。このとき，自由表面の位置 と圧力が次式のように表されるとする。

$$
\begin{aligned}
& x_{\varepsilon}(y, t)=x_{s}(t)+\varepsilon e^{\omega t} \cos (k y) \\
& p_{\varepsilon}(x, y, t)=p_{0}(x, t)+\varepsilon g(x) e^{\omega t} \cos (k y)
\end{aligned}
$$

ここで， $\omega$ は摂動の成長速度， $k=2 \pi \lambda$ は摂動の無次元波数， $\lambda$ は摂動の無次元波長である. 式 (24) を式 (11) に 代入すると，圧力摂動の分布を表す $g(x)$ に関する微分方程式を得る。

$$
\frac{d^{2} g}{d x^{2}}+\frac{3}{h} \frac{d h}{d x} \frac{d g}{d x}-k^{2} g=0
$$

ここでは自由表面近傍における振るまいが知りたいので, 式 (25) の左辺第二項の係数を $x=x_{s}$ 周りで Taylor 展 開し，

$$
\frac{3}{h} \frac{d h}{d x} \approx \frac{36 C a^{\circ} \alpha(1+\dot{\delta}) x_{s}}{h_{B}^{4}}
$$

と近似すると，一般解は次式のようになる。

$$
g(x)=C_{1} e^{-\frac{1}{2}\left(c+\sqrt{c^{2}+4 k^{2}}\right) x}+C_{2} e^{-\frac{1}{2}\left(c-\sqrt{c^{2}+4 k^{2}}\right) x}
$$

ここで, $C_{1}$ と $C_{2}$ は未定係数であり, $g(x)$ に関する境界条件から求められる．また，

$$
c=\frac{36 C a^{\circ} \alpha(1+\dot{\delta}) x_{s}}{h_{B}^{4}}
$$

である。 
式 (26)の一般解に含まれる未定係数を決定するために, 自由表面上における $g(x)$ の境界条件を求める. そこで, 摂動を受けた界面における圧力の境界条件を考える。一般に，交じり合わない 2 つの流体の界面における法線方 向の力のつりあいは次式で表される.

$$
p_{1}-p_{2}+\sigma \kappa=2 \mu_{1} \frac{\partial u_{1}^{n}}{\partial n}-2 \mu_{2} \frac{\partial u_{2}^{n}}{\partial n}
$$

ここで, $i=1,2$ は流体の種類を表し, $p_{i}$ は圧力， $\sigma$ は表面張力係数， $\kappa$ は界面の平均曲率， $\mu_{i}$ は粘度， $u_{i}$ は流速で あり, $n$ は界面の法線ベクトルである. 式 (28) において, 流体 1 として空気を考え, その圧力を基準として $p_{1}=0$ とおく．また，流体 2 として高粘度の液体を考え， $\mu_{1} \ll \mu_{2}$ として $\mu_{1}=0$ とおく，その結果，次式を得る。

$$
p_{2}=\sigma \kappa+2 \mu_{2} \frac{\partial u_{2}^{n}}{\partial n}
$$

上式を基礎式と同様に無次元化し，本研究の場合に適用すると，粘性応力を考慮した自由表面上の圧力の境界条 件を得る.

$$
p\left(x_{s}\right)=-\frac{2 \beta}{h_{B}}+\left.2 C a \frac{d u}{d x}\right|_{x=x_{s}}
$$

ここで, $C a=\mu V_{s} / \sigma$ でる. 上式の右辺第二項は粘性応力の効果を表している.

従来の研究では, 流体の粘度が低く, キャピラリ数が十分小さいとして粘性応力を無視した解析が行われてい る.このような仮定はキャピラリ数が 1 より小さな範囲では十分よい精度で成り立つ. しかし, 流体の粘度が高 く, キャピラリ数が 1 より大きくなる条件の下で行われた Hele-Shaw セルにおける実験の結果は, 粘性応力を無 視した解析では説明できない傾向を示すことが知られており (Maxworthy, 1989), 近年，粘性応力を考慮した理論 解析が行われている (Fernandez, et al., 2001, Gadêlha and Miranda, 2009, Kim, et al., 2009, 舟田他, 2011, Nagel and Gallaire, 2013).

本研究では，比較的粘度の高い流体を対象としているため，このような粘性応力の効果を無視できない. した がって, 以下では簡易的に粘性応力の効果を取り入れた解析を行う。また，流体の粘度が高くなると，板面上に形 成される残留液膜の厚さが大きくなり，その影響も無視できなくなると思われる (図 2(c))．以下の計算ではこの 残留液膜の効果も考慮する。

式 (8) をすき間方向に平均化した $x$ 方向の流速 $\bar{u}$ は次式で与えられる.

$$
\bar{u}(x)=\frac{1}{h} \int_{-h / 2}^{h / 2} u d z=-\frac{h^{2}}{12 C a^{\circ} \beta^{-1}} \frac{d p_{0}}{d x}
$$

これは多孔質媒体中における流れの流速分布を与えるDarcy 則に等しい. 残留液膜厚さとすき間の比を $m$ とする と，自由表面の移動速度 $U$ と平均速度 $\bar{u}$ との関係は次式で与えられる (Reinelt, 1987).

$$
\bar{u}\left(x_{s}\right)=(1-m) U
$$

厳密には $m$ は時間と空間の関数であるが，ここでは簡単のため， $m$ を実験条件によって定まる修正キャピラリ数の 関数として $m=m\left(\mathrm{Ca}^{\circ}\right)$ とする. 残留液膜厚さの比とキャピラリ数の関係は実験的に調べられており (Taylor, 1960), 実験結果に基づく経験的な $m$ の関数近似式が提案されている (Aussillous and Quéré, 2000). しかし，これは基本的 に円管内の軸対称流れの実駼結果に基づいており，平行平板間における流れとは状況が異なる，そこで，本研究 では平行平板間における流れの境界要素シミュレーションから求められた次式を用いる (古口他, 1995).

$$
m=0.362861-0.154134005 \exp \left(-1.124132739 \mathrm{Ca}^{\circ} \beta^{-2}\right)
$$

式 (31) と式 (32) を式(30) に代入し, 界面上の圧力を次式で計算する.

$$
p\left(x_{s}\right)=-\frac{2 \beta}{h_{B}}-\left.\frac{\bar{m} h_{B}^{2}}{6 \beta^{2}}\left(\frac{2}{h_{B}} \frac{d h}{d x} \frac{d p_{0}}{d x}+\frac{d^{2} p_{0}}{d x^{2}}\right)\right|_{x=x_{s}}
$$

ここで, $\bar{m}=1 /(1-m)$ である. 上式に式 (23) と式 (24)を代入すると次式を得る.

$$
p_{0}\left(x_{\varepsilon}\right)+\bar{\varepsilon} g\left(x_{\varepsilon}\right)=-\frac{2 \beta}{h\left(x_{\varepsilon}\right)}+\bar{\varepsilon} k^{2}-\left.\frac{\bar{m} h\left(x_{\varepsilon}\right)^{2}}{6 \beta^{2}}\left[\frac{2}{h\left(x_{\varepsilon}\right)} \frac{d h}{d x}\left(\frac{d p_{0}}{d x}+\bar{\varepsilon} \frac{d g}{d x}\right)+\frac{d^{2} p_{0}}{d x^{2}}+\bar{\varepsilon} \frac{d^{2} g}{d x^{2}}\right]\right|_{x=x_{s}}
$$


ここで, $\bar{\varepsilon}=\varepsilon e^{\omega t} \cos (k y)$ とおいた. 上式を線形化して $O(\varepsilon)$ の項を比較すると,

$$
\begin{aligned}
g\left(x_{s}\right)=k^{2} & -\frac{d p_{0}}{d x}+\left.\frac{2 \beta}{h_{B}^{2}} \frac{d h}{d x}\right|_{x=x_{s}} \\
& -\left.\frac{\bar{m} h_{B}^{2}}{6 \beta^{2}}\left[2\left\{\left(\frac{1}{h_{B}} \frac{d h}{d x}\right)^{2}+\frac{1}{h_{B}} \frac{d^{2} h}{d x^{2}}\right\} \frac{d p_{0}}{d x}+\frac{2}{h_{B}} \frac{d h}{d x}\left(2 \frac{d^{2} p_{0}}{d x^{2}}+\frac{d g}{d x}\right)+\frac{d^{3} p_{0}}{d x^{3}}+\frac{d^{2} g}{d x^{2}}\right]\right|_{x=x_{s}}
\end{aligned}
$$

さらに式 (25)の関係を考慮することで, 自由表面上の $g(x)$ の境界条件が次式のように得られる.

$$
g\left(x_{s}\right)=\left(k^{2}-\left.\left(\frac{d p}{d x}-\frac{2 \beta}{h_{B}^{2}} \frac{d h}{d x}+\frac{\bar{m} h_{B}^{2}}{6 \beta^{2}} f(x)\right)\right|_{x=x_{s}}\right) /\left(1+\frac{\bar{m} h_{B}^{2}}{6 \beta^{2}} k^{2}\right)
$$

ここで,

$$
f(x)=2\left\{\left(\frac{1}{h(x)} \frac{d h}{d x}\right)^{2}+\frac{1}{h(x)} \frac{d^{2} h}{d x^{2}}\right\} \frac{d p_{0}}{d x}+\frac{1}{h(x)} \frac{d h}{d x}\left(4 \frac{d^{2} p_{0}}{d x^{2}}-\frac{d g_{0}}{d x}\right)+\frac{d^{3} p_{0}}{d x^{3}}
$$

である．また， $g_{0}(x)$ は粘性応力を考慮しない場合の式 (25)の解であり，次式で表される.

$$
g_{0}(x)=\left(k^{2}-\left.\left(\frac{d p}{d x}-\frac{2 \beta}{h_{B}^{2}} \frac{d h}{d x}\right)\right|_{x=x_{s}}\right) \exp \left[-\frac{c}{2}\left(x-x_{s}\right)\right] \frac{K \cosh (K x / 2)+c \sinh (K x / 2)}{K \cosh \left(K x_{s} / 2\right)+c \sinh \left(K x_{s} / 2\right)}
$$

ここで, $K=\sqrt{c^{2}+4 k^{2}}$ である. 式 (37) と系の対称性を考慮することで式 (26) の未定係数が定まり, 求める $g(x)$ の解が次式のように得られる。

$$
g(x)=g\left(x_{s}\right) \exp \left[-\frac{c}{2}\left(x-x_{s}\right)\right] \frac{K \cosh (K x / 2)+c \sinh (K x / 2)}{K \cosh \left(K x_{s} / 2\right)+c \sinh \left(K x_{s} / 2\right)}
$$

得られた $g(x)$ を用いて $\omega$ と $k$ の関係式を求める. 式 (23) を時間で微分すると, 摂動を受けた自由表面の速度を 得る.

$$
\frac{d x_{\varepsilon}}{d t}=\frac{d x_{s}}{d t}+\varepsilon \omega e^{\omega t} \cos (k y)
$$

また, 式 (31) と式 (32) から求まる速度分布に, 摂動を受けた自由表面の位置を代入しても自由表面の速度 $U_{\varepsilon}$ が 得られる。

$$
U_{\varepsilon}=-\left.\frac{\bar{m} h\left(x_{\varepsilon}\right)^{2}}{12 C a^{\circ} \beta^{-1}} \frac{d p_{0}}{d x}\right|_{x=x_{\varepsilon}}
$$

式(42)を $O(\varepsilon)$ で線形化し, 式 (41) と比較することで, $k$ の関数として $\omega$ の式を得る.

$$
\omega=-\left.\frac{\bar{m} h_{B}^{2}}{12 C a^{\circ} \beta^{-1}}\left(\frac{2}{h} \frac{d h}{d x} \frac{d p_{0}}{d x}+\frac{d g}{d x}+\frac{d^{2} p_{0}}{d x^{2}}\right)\right|_{x=x_{s}}
$$

本研究では摂動の振幅が小さい流れの極初期の安定性を調べるため, 上式において $t=0, x_{s}=1 / 2$ とする． $\omega$ は 摂動が時間的に成長するかどうかを表しており， $\omega>0$ ならば自由表面は不安定である．実験において実際に観 測される摂動の波数は，この条件を満たし，かつ成長速度が最大のときのものであると考えられる (西浦，2009). したがって,

$$
\frac{d \omega}{d k}=0
$$

を満たす $k_{\max }$ が求める摂動の波数である. 式 (44) は $k$ に関する非線形方程式であるため, この式を $C a^{\circ}, \alpha, \beta$ を パラメータとしてニュートン法によって数值的に解き， $k_{\max }$ を求める.

弾性シートの変形が無視できる場合には，式 (44) は解析的に解くことができて, $C a^{\circ}$ との関係式が次式のよ うに得られる。

$$
C a^{\circ}=\frac{k^{2}}{6}\left(\frac{\bar{m} k^{3}+6 k \beta^{2}+\left(\bar{m} k^{2}+18 \beta^{2}\right) \sinh k}{\bar{m} k^{3}+6 k \beta^{2}-\left(\bar{m} k^{2}-6 \beta^{2}\right) \sinh k}\right)
$$

上式において $k \ll 1$ のときは $k \sim \sqrt{3 C a^{\circ}}$ が成り立つ。これより, シートの変形と粘性応力を考慮しない場合には, $\lambda$ は $\mathrm{Ca}^{\circ}$ の関数として次式のように表される.

$$
\lambda \sim \frac{2 \pi}{\sqrt{3 C a^{\circ}}}
$$


Table 1 Experimental condition

\begin{tabular}{ll}
\hline \multicolumn{1}{c}{ Properties } & \multicolumn{1}{c}{ Values } \\
\hline$h_{0}, \mathrm{~mm}$ & $0.3,0.5,0.75,1.0$ \\
$V_{s}, \mathrm{~mm} / \mathrm{min}$ & $0.5,1,2,5,10,20,50,100$ \\
$\alpha$ & $17.1 \times 10^{-6}, 10.3 \times 10^{-6}, 6.84 \times 10^{-6}, 5.13 \times 10^{-6}$ \\
\hline
\end{tabular}

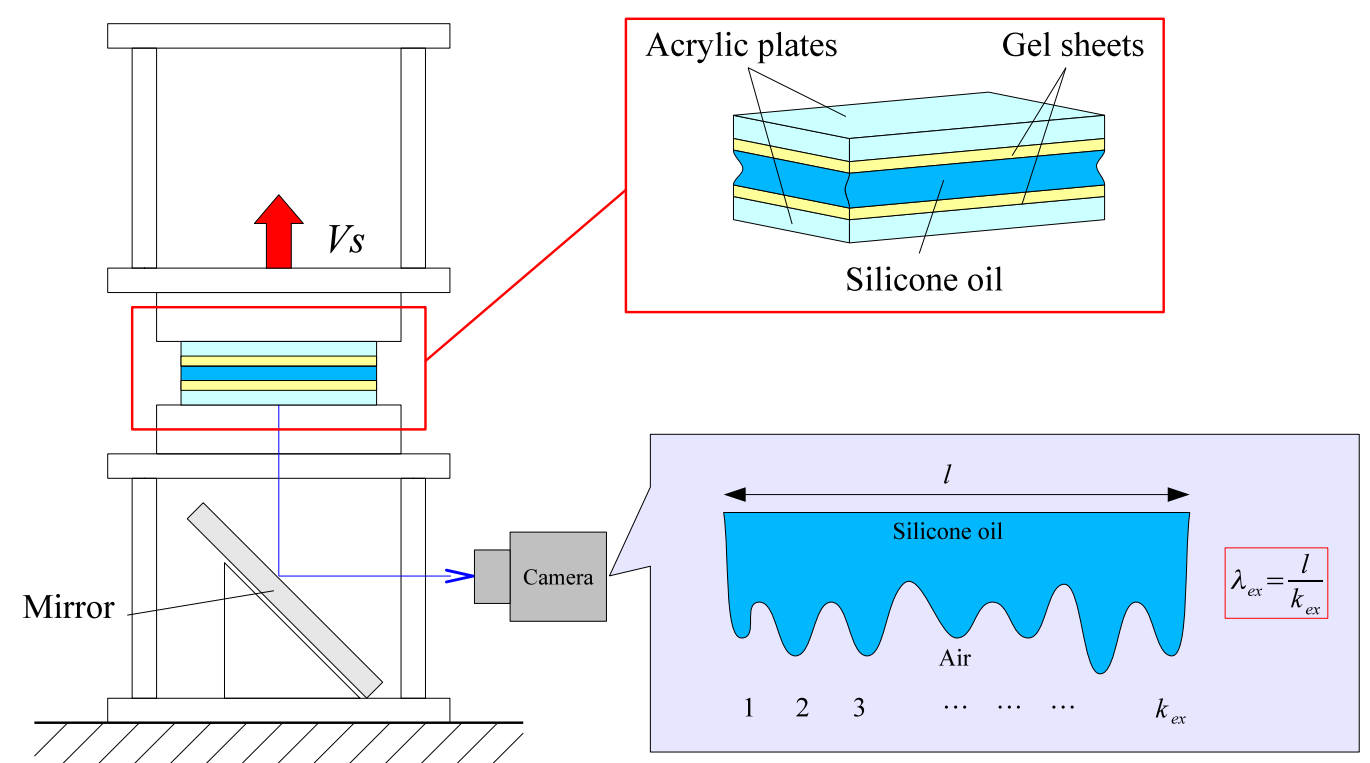

Fig. 3 Schematic view of the experimental equipment. Silicone oil is filled in a narrow gap between two gel sheets bonded to the acrylic substrate. Then, the upper plate is pulled up at a constant velocity using a tensile test machine. The video camera records the motion of the free surface through the lower mirror. The perturbation wavelength at the onset of the growth of the instability is measured using snapshots obtained by a camera. The experimental wavelength $\lambda_{e x}$ is given by $\lambda_{e x}=l / k_{e x}$. Where $l$ is the length of the measuring area in the width direction and $k_{e x}$ is the number of peak of the perturbation per $l$.

\section{3. 実験}

\section{$3 \cdot 1$ 実験方法}

実験は図 3 のように行った。 $L=30 \mathrm{~mm}, B=100 \mathrm{~mm}, E_{u}=E_{l}=0.83 \mathrm{MPa}, d_{u}=d_{l}=3 \mathrm{~mm}$ のゲルシート（ハ イパーゲル 3030T，(株)エクシールコーポレーション) を2枚，図 1 のように平行なアクリル板に接着し，その間 に粘度 $\mu=9.75 \mathrm{~Pa} \cdot \mathrm{s}$ ，表面張力係数 $\sigma=21.3 \mathrm{mN} / \mathrm{m}$ のシリコーンオイル (KF-96 1 万 cSt, (株) 信越シリコーン) を満たす，その後，引張試験機を用いて上側の基板を一定速度で引き離し，そのときの自由表面の様子を下側に設 置したミラーを通してビデオカメラで撮影する。そして，得られた画像から摂動成長の初期段階における波長を測 定する. 図 4 に $h_{0}=0.5 \mathrm{~mm}, V_{s}=10 \mathrm{~mm} / \mathrm{min}$ のときの実際の自由表面のパターンの例を示す. 図 4(a) は $t=1.5 \mathrm{~s}$ における全体図であり，自由表面の乱れが十分成長したときのものである．図 4(b) から図 4(e) は各時刻に対する 測定領域付近の自由表面の形状である. 波長の測定は幅方向の流れの影響が小さい板の中心 $(y=0)$ 付近で行い, 摂動の振幅が小さな時点（図 4(c) 程度）に行った（図 3 右下）。実験における波長 $\lambda_{e x}$ は $\lambda_{e x}=l / k_{e x}$ として求めた。 ここで， $l$ は測定を行う領域の幅方向の基準長さ， $k_{e x}$ は測定領域に含まれる乱れた自由表面の山（谷）の数であ る。実験は 4 種類の初期すき間に対して引き離し速度を変えていくことで行った．表 1 に実験条件を示す．実験は 各条件で 3 回ずつ行い，その平均を求めた。また，同じ寸法のアクリル板に対しても同一の条件で実験を行った。

\section{$3 \cdot 2$ 実験結果および考察}

図 5 に摂動波長の測定結果を示す。横軸は修正キャピラリ数 $C a^{\circ}$ であり，縦軸は板の長さで有次元化した摂動 波長 $\lambda^{*}$ であり, $\lambda^{*}=L \lambda$ である. 中実のマーカーはゲルシート, 中空はアクリル板の実験結果であり, 色の違い が初期すき間の違いに対応する。図中の実線の曲線は式 (45)，黒い直線は式 (46)である.

図 5 を見ると, $C a^{\circ}$ が小さな領域では波長はおおむね式 (46) に従う。この領域は流体の粘度が低いまたは自由 


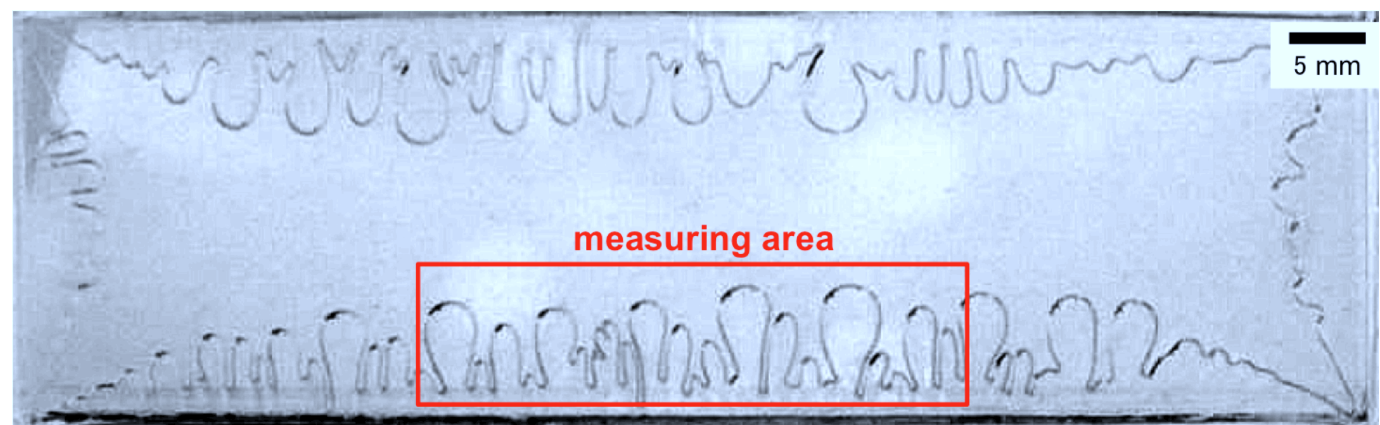

(a) Overall $\operatorname{view}(t=1.5 \mathrm{~s})$

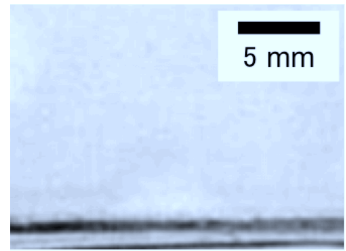

(b) $t=0.0 \mathrm{~s}$

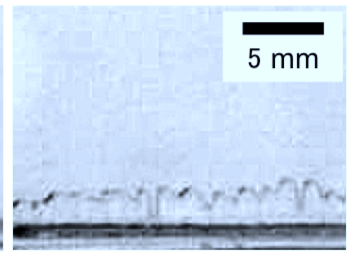

(c) $t=0.5 \mathrm{~s}$

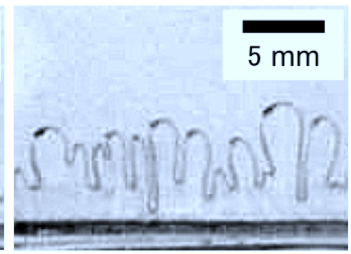

(d) $t=1.0 \mathrm{~s}$

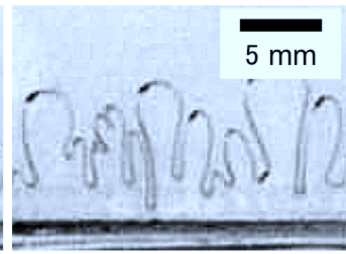

(e) $t=1.5 \mathrm{~s}$

Fig. 4 Typical images of the disturbed free surface. (a) Overall view of a sufficient grown dendritic pattern at $t=1.5 \mathrm{~s}$. The wavelength was measured in the area denoted by red frame, where the influence of flow in the width direction can be neglected. (b-d) The shape of the free surface at each time. The length of scale bar denoted by a black line is $5 \mathrm{~mm}$.

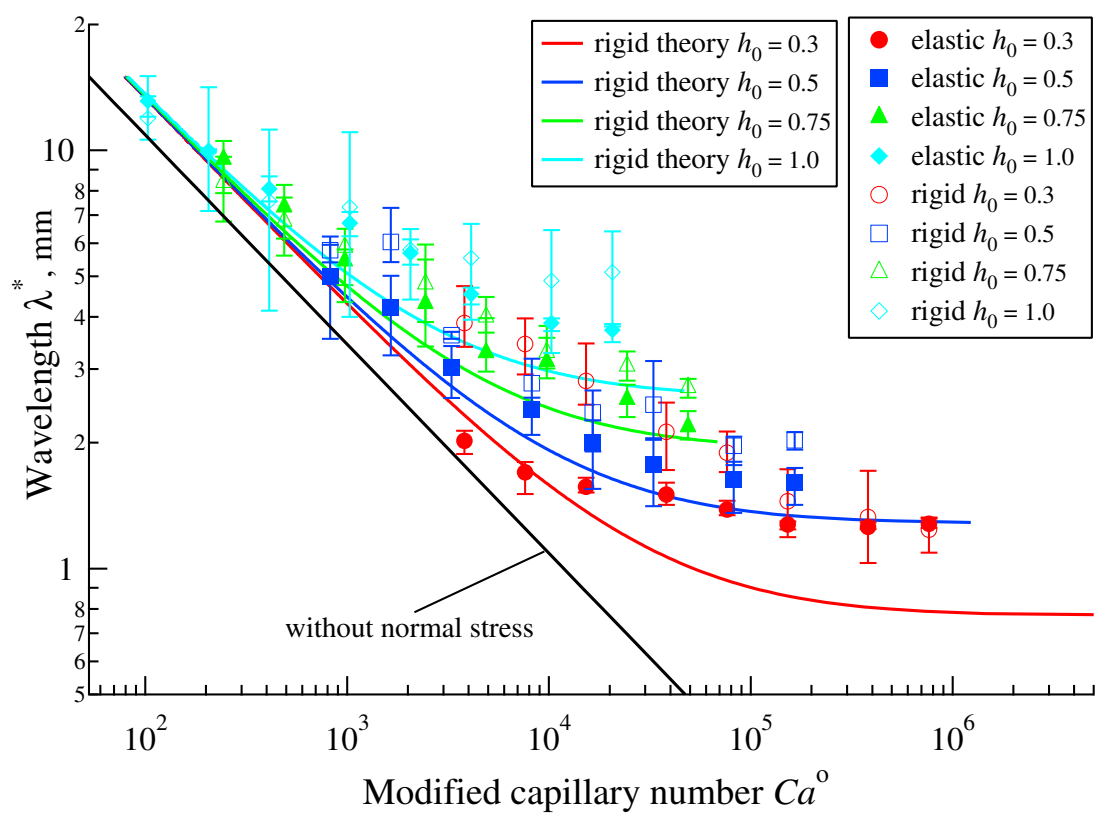

Fig. 5 A relatipnship between the wavelength of disturbance on the free surface against the modified capillary number. The solid and open marks indicate the experimental results of gel sheet and acrylic plate, respectively. The solid curves and line are theoretical results corresponding to Eq. (45) and (46). Where $\lambda^{*}=L \lambda$ is the dimensional wavelength multiplied by length of the sheet $L$.

表面の移動速度が小さい場合に相当し，従来の理論解析の傾向にも一致する.しかし，C $a^{\circ}$ が大きくなると摂動波 長は各初期すき間ごとに対応した一定值に漸近する。この領域では自由表面における粘性応力が無視できなくな る程に大きくなり, 自由表面近傍の圧力は表面張力ではなく粘性応力とつり合うようになるため, 摂動波長はあ る一定の值より小さくならない，このような傾向は粘性応力を考虑しなければ再現することができない。この波 長の最小值は, 本研究の結果では, 残留液膜を考慮しない場合 $\lambda_{\min }^{*} \sim 2.6 h_{0}$ 程度, 考慮する場合 $\lambda_{\min }^{*} \sim 3.2 h_{0}$ 程度 となった。粘性応力を考慮した先行研究では, $\lambda_{\min }^{*}$ の值は Fernandez らが $2.3 h_{0}$ (Fernandez, et al., 2001), Kim ら 


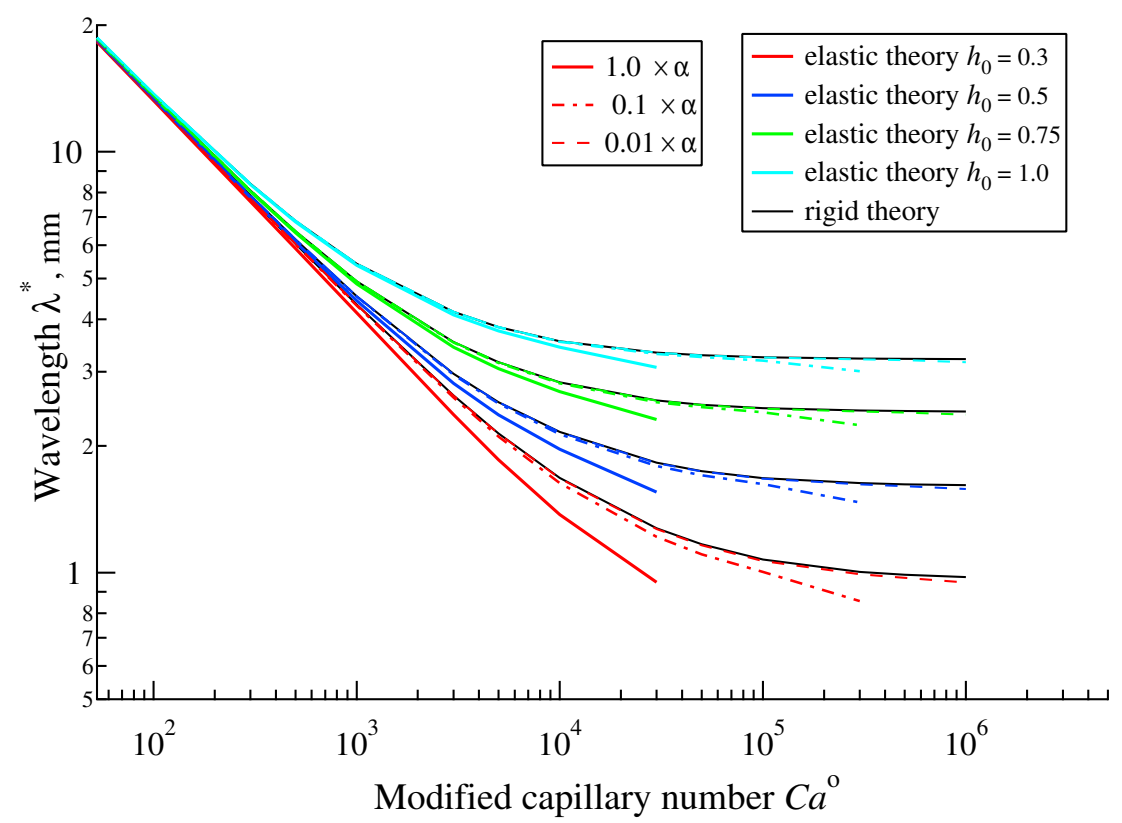

Fig. 6 Comparison of theoretical results. Colored curves are results taking into account for elastic deformation. Solid, dotted and dashed lines correspond to magnification of the elastic parameter $\alpha$, which are $1,0.1$ and 0.01 , respectively. Black curves denote the results neglecting deformation.

が 2.6h (Kim, et al., 2009), Nagel と Gallaire が 2.5 $h_{0}$ (Nagel and Gallaire, 2013) 程度であるとそれぞれ報告してい る。これらの研究では, いずれも残留液膜の効果は考慮されていない。しかし, 本研究で得られた実験結果では, $\lambda_{\min }^{*} \sim 3.0 h_{0}$ から $5.0 h_{0}$ 程度となり, 残留液膜を考慮することによって理論值が実験結果により近づくことがわか る。これは流体の粘度が高くなると, 粘性応力と同様に残留液膜の効果も無視できなくなるためであると考えら れる。したがって, 特に高粘性流体を対象とする場合には残留液膜の効果を考慮する必要があると思われる。し かし，残留液膜の効果だけでは，特に初期すき間が小さい場合の最小波長の実験結果は説明できない. 理論解析 によれば，最小波長と初期すき間の比は常に一定となるはずであるが，たとえば， $h_{0}=0.3 \mathrm{~mm}$ の実験における最 小波長は，理論が予測する值よりも大きくなり，結果として $\lambda_{\text {min }}^{*} \sim 5.0 h_{0}$ 程度となっている．このことから，初期 すき間が小さくなっていく $h_{0} \rightarrow 0$ の場合にも波長の最小值が存在する可能性があると予想される。これはすき間 方向の流れ場の影響が大きくなるためであると思われる．初期すき間がサブミクロンオーダー程度まで小さくな れば, さらに板面の表面性状（粗さ，濡れ性）などの影響も無視できなくなる。したがって, 現象の解明には流 れの三次元性や壁面の摩擦・接触角の効果などを考慮した, より詳細な理論解析が必要であると考元られる.

図 6 は弾性シートの変形を考慮した理論解析の結果である。実線は表 1 における $\alpha$ の值に対応し，一点鎖線は $\alpha$ を 0.1 倍, 点線は 0.01 倍したものである. 黒の実線は変形を考慮しない場合の式 (45) である. 弾性シートがす き間方向に変形すると，すき間が狭まることによって圧力が大きくなり，自由表面の移動速度は大きくなる，その 結果, 自由表面はより不安定になるので, 同一の修正キャピラリ数に対して摂動波長は平行平板間の場合よりも 小さくなる．図 6 はこの結果を示しており，変形を考慮した波長は考慮しない場合に比べて小さくなっている.

図 5 と図 6 を比較すると，ゲルシート間における波長の実験值は変形を考慮しない理論式 (45) とよく一致して いる. これは今回の実験条件では, ゲルシートが薄く, 流体に生じる圧力も小さいため, 実験におけるゲルシート の変形が小さかったためだと思われる。本研究では弾性シートの変形を単純な線形ばねによってモデル化してい るため, 実際の三次元的な変形は表現できない. しかし, 図 5 を見ると, ゲルシート間における波長は, 程度の 差はあるが，おおむね攵ルシートがない場合の波長に比べて小さい. この傾向は図 6 の結果と定性的に一致して いる。したがって，変形によってすき間が狭まることで自由表面はより不安定になるものと考えられる. 


\section{4. 結 言}

本研究では, 弾性シート間の粘性流体の自由表面に対する線形安定性解析を行い, 修正キャピラリ数と摂動波 長の関係式を求め，実験で測定した波長と比較した。その結果，以下の結論を得た.

1. 自由表面上の粘性応力を考慮することによって, 修正キャピラリ数が大きな範囲でも波長の理論值と実験值 はよく一致した。

2. 最小波長の理論值は初期すき間の 3.2 倍程度となり, 残留液膜の効果を考慮することによって既往の研究 (2.3 〜2.6 倍）よりも実験結果に近い值を得ることができた。しかし，実験の最小波長は初期すき間の 3.0 5.0 倍 の範囲でばらつきが見られた。これは初期すき間が小さくなるにしたがって，流れの三次元性などの影響が 大きくなったためであると考えられる.

3. 弾性シート間における波長の実験值は平行平板間における波長に比べて小さく，この傾向は理論解析と定性 的に一致した。

\section{文献}

Al-Housseiny, T. T., Christov, I. C. and Stone, H. A., Two-phase fluid displacement and interfacial instabilities under elastic membranes, Physical Review Letters, Vol.111, 034502(2013), DOI:10.1103/PhysRevLett.111.034502.

Aussillous, P. and Quéré, D., Quick deposition of a fluid on the wall of a tube, Physics of Fluids, Vol.12, No.10(2000), pp.2367-2371.

Bales, G. S., Redfield, A. C. and Zangwill, A., Growth dynamics of chemical vapor deposition, Physical Review Letters, Vol.62(1989), pp.776-779.

Biggins, J. S., Saintyves, B., Wei, Z., Bouchaud, E. and Mahadevan, L., Digital instability of a confined elastic meniscus, Proceedings of the National Academy of Sciences, Vol.110, No.31(2013), pp.12545-12548.

Chung, J. Y., Kim, K. H., Chaudhury, M. K., Sarkar, J. and Sharma, A., Confinement-induced instability and adhesive failure between dissimilar thin elastic films, The European Physical Journal E, Vol.20, No.1(2006), pp.47-53.

Fernandez, J., Kurowski, P., Limat, L. and Petitjeans, P., Wavelength selection of fingering instability inside hele-shaw cells, Physics of Fluids, Vol.13, No.11(2001), pp.3120-3125.

舟田敏雄, 金子裕哉, 鈴木秀, 様々なへルショウセルの粘性ポテンシャル流解析 (1), 沼津工業高等専門学校研究報告, Vol.45(2011), pp.247-252.

Gadêlha, H. and Miranda, J., Effects of normal viscous stresses on radial viscous fingering, Physical Review E, Vol.79, 066312(2009), DOI:10.1103/PhysRevE.79.066312.

Ghatak, A., Chaudhury, M. K., Shenoy, V. and Sharma. A., Meniscus instability in a thin elastic film, Physical Review Letters, Vol.85(2000), pp.4329-4332.

Ghatak, A., Mahadevan, L. and Chaudhury, M. K., Measuring the work of adhesion between a soft confined film and a flexible plate, Langmuir, Vol.21, No.4(2005), pp.1277-1281.

Glicksman, M. E. and Lupulescu, A. O., Dendritic crystal growth in pure materials, Journal of Crystal Growth, Vol.264, No.4(2004), pp.541-549.

Grillet, A., Lee, L. and Shaqfeh, E. S. G., Observations of ribbing instabilities in elastic fluid flows with gravity stabilization, Journal of Fluid Mechanics, Vol.399(1999), pp.49-83.

Hidalgo, J. and Carrera, J., Effect of dispersion on the onset of convection during co2 sequestration, Journal of Fluid Mechanics, Vol.640(2009), pp.441-452.

Kim, H., Funada, T., Joseph, D. D. and Homsy, G. M., Viscous potential flow analysis of radial fingering in a hele-shaw cell, Physics of Fluids, Vol.21, No.7(2009), DOI:10.1063/1.3184574.

古口日出男, 西巻保紀, 関根健生, 境界要素法による平行 2 円板間の液膜のメニスカス不安定現象のシミュレーション, 日本機械 学会論文集 B 編, Vol.61, No.585(1995), pp.1654-1660.

古口日出男, 岡田昌章, 傾斜平板間の液膜のメニスカス不安定性 : 第 1 報, ニュートン流体の場合, 日本機械学会論文集 B 編, Vol.53, No.491(1987), pp.2062-2069.

古口日出男, 関根健生, 矢田敏夫, 境界要素法による平行二平板間の狭いすき間内の移動メニスカスの解析, 日本機械学会論文集 B 編, Vol.60, No.570(1994), pp.438-445. 
古口日出男, 田村勝義, 矢田敏夫, メニスカス不安定理論による分離面パターンの解析, 日本機械学会論文集 B 編, Vol.54, No.505(1988), pp.2446-2451.

Lindner, A., Derks, D. and Shelley, M. J., Stretch flow of thin layers of newtonian liquids: Fingering patterns and lifting forces, Physics of Fluids, Vol.17, No.7(2005), DOI:10.1063/1.1939927.

Maxworthy, T., Experimental study of interface instability in a hele-shaw cell, Physical Review A, Vol.39(1989), pp.5863-5866.

McLean, J. W. and Saffman, P. G., The effect of surface tension on the shape of fingers in a hele shaw cell. Journal of Fluid Mechanics, Vol.102(1981), pp.455-469.

Nagel, M. and Gallaire, F., A new prediction of wavelength selection in radial viscous fingering involving normal and tangential stresses, Physics of Fluids, Vol.25, No.12(2013), DOI:10.1063/1.4849495.

Nase, J., Derks, D. and Lindner, A., Dynamic evolution of fingering patterns in a lifted hele-shaw cell, Physics of Fluids, Vol.23, No.12(2011), DOI:10.1063/1.3659140.

西浦廉政, 非平衡ダイナミクスの数理, 岩波書店 (2009), pp.85-95.

Park, C. W., Gorell, S. and Homsy, G. M., Two-phase displacement in hele-shaw cells: experiments on viscously driven instabilities, Journal of Fluid Mechanics, Vol.141(1984), pp.275-287.

Park, C. W. and Homsy, G. M., Two-phase displacement in hele shaw cells: theory, Journal of Fluid Mechanics, Vol.139(1984), pp.291-308.

Pihler-Puzović, D., Juel, A. and Heil, M., The interaction between viscous fingering and wrinkling in elastic-walled hele-shaw cells, Physics of Fluids, Vol.26, No.2(2014), DOI:10.1063/1.4864188.

Pihler-Puzović, D., Périllat, R., Russell, M., Juel, A. and Heil, M., Modelling the suppression of viscous fingering in elastic-walled hele-shaw cells, Journal of Fluid Mechanics, Vol.731(2013), pp.162-183.

Pihler-Puzović, D., Illien, P., Heil, M. and Juel, A., Suppression of complex fingerlike patterns at the interface between air and a viscous fluid by elastic membranes, Physical Review Letters, Vol.108, 074502(2012), DOI:10.1103/PhysRevLett.108.074502.

Pitts, E., Penetration of fluid into a hele-shaw cell: the saffman-taylor experiment, Journal of Fluid Mechanics, Vol.97(1980), pp.53-64.

$\mathrm{Qu}$, R. T. and Zhang, Z. F., Compressive fracture morphology and mechanism of metallic glass, Journal of Applied Physics, Vol.114, No.19(2013), DOI:10.1063/1.4830029.

Reinelt, D. A., Interface conditions for two-phase displacement in hele-shaw cells, Journal of Fluid Mechanics, Vol.183(1987), pp.219234.

Saffman, P. G., Viscous fingering in hele-shaw cells, Journal of Fluid Mechanics, Vol.173(1986), pp.73-94.

Saffman, P. G. and Taylor, G., The penetration of a fluid into a porous medium or hele-shaw cell containing a more viscous liquid, Proceedings of the Royal Society of London. Series A. Mathematical and Physical Sciences, Vol.245, No.1242(1958), pp.312329.

Saintyves, B., Dauchot, O. and Bouchaud, E., Bulk elastic fingering instability in hele-shaw cells, Physical Review Letters, Vol.111, 047801(2013), DOI:10.1103/PhysRevLett.111.047801.

佐々木成人, 同時多層リバースコーティングにおけるロール間流動状態の可視化, 鉄と鋼, Vol.100, No.5(2014), pp.639-646.

Shelley, M. J., Tian, F. R. and Wlodarski, K., Hele - Shaw flow and pattern formation in a time-dependent gap, Nonlinearity, Vol.10(1997), pp.1471-1495.

Taylor, G. I., Deposition of a viscous fluid on a plane surface, Journal of Fluid Mechanics, Vol.9(1960), pp.218-224.

山村方人, 精密ウェットコーティングの基礎, 表面技術, Vol.60, No.7(2009), pp.420-420.

\section{References}

Al-Housseiny, T. T., Christov, I. C. and Stone, H. A., Two-phase fluid displacement and interfacial instabilities under elastic membranes, Physical Review Letters, Vol.111, 034502(2013), DOI:10.1103/PhysRevLett.111.034502.

Aussillous, P. and Quéré, D., Quick deposition of a fluid on the wall of a tube, Physics of Fluids, Vol.12, No.10(2000), pp.2367-2371.

Bales, G. S., Redfield, A. C. and Zangwill, A., Growth dynamics of chemical vapor deposition, Physical Review Letters, Vol.62(1989), pp.776-779.

Biggins, J. S., Saintyves, B., Wei, Z., Bouchaud, E. and Mahadevan, L., Digital instability of a confined elastic meniscus, Proceedings of the National Academy of Sciences, Vol.110, No.31(2013), pp.12545-12548. 
Chung, J. Y., Kim, K. H., Chaudhury, M. K., Sarkar, J. and Sharma, A., Confinement-induced instability and adhesive failure between dissimilar thin elastic films, The European Physical Journal E, Vol.20, No.1(2006), pp.47-53.

Fernandez, J., Kurowski, P., Limat, L. and Petitjeans, P., Wavelength selection of fingering instability inside hele-shaw cells, Physics of Fluids, Vol.13, No.11(2001), pp.3120-3125.

Funada, T., Kaneko, Y. and Suzuki, S., Viscous Potential Flow Analysis of Various Hele-Shaw Cells (1), Memoirs of Numazu College of Technology, Vol.45(2011), pp.247-252(in Japanese).

Gadêlha, H. and Miranda, J., Effects of normal viscous stresses on radial viscous fingering, Physical Review E, Vol.79, 066312(2009), DOI:10.1103/PhysRevE.79.066312.

Ghatak, A., Chaudhury, M. K., Shenoy, V. and Sharma. A., Meniscus instability in a thin elastic film, Physical Review Letters, Vol.85(2000), pp.4329-4332.

Ghatak, A., Mahadevan, L. and Chaudhury, M. K., Measuring the work of adhesion between a soft confined film and a flexible plate, Langmuir, Vol.21, No.4(2005), pp.1277-1281.

Glicksman, M. E. and Lupulescu, A. O., Dendritic crystal growth in pure materials, Journal of Crystal Growth, Vol.264, No.4(2004), pp.541-549.

Grillet, A., Lee, L. and Shaqfeh, E. S. G., Observations of ribbing instabilities in elastic fluid flows with gravity stabilization, Journal of Fluid Mechanics, Vol.399(1999), pp.49-83.

Hidalgo, J. and Carrera, J., Effect of dispersion on the onset of convection during co2 sequestration, Journal of Fluid Mechanics, Vol.640(2009), pp.441-452.

Kim, H., Funada, T., Joseph, D. D. and Homsy, G. M., Viscous potential flow analysis of radial fingering in a hele-shaw cell, Physics of Fluids, Vol.21, No.7(2009), DOI:10.1063/1.3184574.

Koguchi, H., Nishimaki, Y. and Sekine, T., Simulation of breakup of thin liquid film between parallel circular plates using boundary element method, Transactions of the Japan Society of Mechanical Engineers, Series B, Vol.61, No.585(1995), pp.1654-1660(in Japanese).

Koguchi, H. and Okada, M., The meniscus instability of a thin liquid film between tilted plates : 1st report, the case of a newtonian fluid, Transactions of the Japan Society of Mechanical Engineers, Series B, Vol.53, No.491(1987), pp.2062-2069(in Japanese).

Koguchi, H., Sekine, T. and Yada, T., Analysis of a moving meniscus in narrow gap between parallel plates by boundary element method, Transactions of the Japan Society of Mechanical Engineers, Series B, Vol.60, No.570(1994), pp.438-445(in Japanese).

Koguchi, H, Tamura, K. and Yada, T., An analysis of patterns on separated surfaces by a meniscus instability theory, Transactions of the Japan Society of Mechanical Engineers, Series B, Vol.54, No.505(1988), pp.2446-2451(in Japanese).

Lindner, A., Derks, D. and Shelley, M. J., Stretch flow of thin layers of newtonian liquids: Fingering patterns and lifting forces, Physics of Fluids, Vol.17, No.7(2005), DOI:10.1063/1.1939927.

Maxworthy, T., Experimental study of interface instability in a hele-shaw cell, Physical Review A, Vol.39(1989), pp.5863-5866.

McLean, J. W. and Saffman, P. G., The effect of surface tension on the shape of fingers in a hele shaw cell. Journal of Fluid Mechanics, Vol.102(1981), pp.455-469.

Nagel, M. and Gallaire, F., A new prediction of wavelength selection in radial viscous fingering involving normal and tangential stresses, Physics of Fluids, Vol.25, No.12(2013), DOI:10.1063/1.4849495.

Nase, J., Derks, D. and Lindner, A., Dynamic evolution of fingering patterns in a lifted hele-shaw cell, Physics of Fluids, Vol.23, No.12(2011), DOI:10.1063/1.3659140.

Nishiura, Y., Mathematics of the far-from-equilibrium dynamics, Iwanami Shoten,Publishers(2009), pp.85-95(in Japanese).

Park, C. W., Gorell, S. and Homsy, G. M., Two-phase displacement in hele-shaw cells: experiments on viscously driven instabilities, Journal of Fluid Mechanics, Vol.141(1984), pp.275-287.

Park, C. W. and Homsy, G. M., Two-phase displacement in hele shaw cells: theory, Journal of Fluid Mechanics, Vol.139(1984), pp.291-308.

Pihler-Puzović, D., Juel, A. and Heil, M., The interaction between viscous fingering and wrinkling in elastic-walled hele-shaw cells, Physics of Fluids, Vol.26, No.2(2014), DOI:10.1063/1.4864188.

Pihler-Puzović, D., Périllat, R., Russell, M., Juel, A. and Heil, M., Modelling the suppression of viscous fingering in elastic-walled hele-shaw cells, Journal of Fluid Mechanics, Vol.731(2013), pp.162-183. 
Pihler-Puzović, D., Illien, P., Heil, M. and Juel, A., Suppression of complex fingerlike patterns at the interface between air and a viscous fluid by elastic membranes, Physical Review Letters, Vol.108, 074502(2012), DOI:10.1103/PhysRevLett.108.074502.

Pitts, E., Penetration of fluid into a hele-shaw cell: the saffman-taylor experiment, Journal of Fluid Mechanics, Vol.97(1980), pp.53-64.

Qu, R. T. and Zhang, Z. F., Compressive fracture morphology and mechanism of metallic glass, Journal of Applied Physics, Vol.114, No.19(2013), DOI:10.1063/1.4830029.

Reinelt, D. A., Interface conditions for two-phase displacement in hele-shaw cells, Journal of Fluid Mechanics, Vol.183(1987), pp.219234.

Saffman, P. G., Viscous fingering in hele-shaw cells, Journal of Fluid Mechanics, Vol.173(1986), pp.73-94.

Saffman, P. G. and Taylor, G., The penetration of a fluid into a porous medium or hele-shaw cell containing a more viscous liquid, Proceedings of the Royal Society of London. Series A. Mathematical and Physical Sciences, Vol.245, No.1242(1958), pp.312329.

Saintyves, B., Dauchot, O. and Bouchaud, E., Bulk elastic fingering instability in hele-shaw cells, Physical Review Letters, Vol.111, 047801(2013), DOI:10.1103/PhysRevLett.111.047801.

Sasaki, M., Visualization study of two layer reverse roll transfer, TETSU-TO-HAGANE, Vol.100, No.5(2014), pp.639-646(in Japanese).

Shelley, M. J., Tian, F. R. and Wlodarski, K., Hele - Shaw flow and pattern formation in a time-dependent gap, Nonlinearity, Vol.10(1997), pp.1471-1495.

Taylor, G. I., Deposition of a viscous fluid on a plane surface, Journal of Fluid Mechanics, Vol.9(1960), pp.218-224.

Yamamura, M., Precision wet coating : Fundamentals., Journal of The Surface Finishing Society of Japan, Vol.60, No.7(2009), pp.420420(in Japanese). 